\title{
DEVELOPING STUDENTS' COMPETENCES FOR THE FUTURE - KEY PRIORITY IN THE ECONOMICS OF UNIVERSITIES
}

\author{
Livia ILIE, Ioan BONDREA \\ "Lucian Blaga" University of Sibiu, Romania \\ livia.ilie@ulbsibiu.ro, ioan.bondrea@ulbsibiu.ro
}

\begin{abstract}
In an interdependent world, marked by deep transformations, higher education institutions must act responsibly: to foresee, anticipate changes in all sectors of society, be ready and able to adjust in accordance with them. The education system in general, higher education in particular, needs to prepare younger generations for these rapid changes and continue challenges. Higher education plays a key role in opening up new horizons through important contributions to a sustained and equitable development and in creating a culture of peace. Higher education institutions must act critically and objectively on the basis of competence and merit, actively promoting intellectual and moral solidarity, serving the intellectual needs. In this complex context, the education system must have a proactive attitude preparing young people to perform in a global context and to adapt continuously through lifelong learning. The higher education system must develop, on one hand, basic skills enabling lifelong learning and on the other hand transferable skills that enable mobility. This paper aims to identify current challenges for the higher education system and to provide an overview on what competencies universities should develop in order to respond to these challenges. An important focus will be on the "Lucian Blaga" University of Sibiu (LBUS) best practice in this respect.
\end{abstract}

Keywords: higher education, competencies, university economics, labour market

Motto: Imagination is more important than knowledge - Albert Einstein

\section{Introduction}

The rapid and deep changes of the $21^{\text {st }}$ century have a major impact on the education system. Internationalization and globalization are real and expanding phenomena. Knowledge and innovation are key factors of economic development, and quality education is vital for the wellbeing of each individual, for the progress of national economies, for a sustainable future of humanity.

The challenges that nations and governments have to face in the current context are:

- the increased importance of the knowledge-based economy; mobility;

- the globalization and talent

- the development information technology and communications.

To ensure economic and social welfare, in the $21^{\text {st }}$ century the labour force has to be competent in respect with the above mentioned challenges and able to learn and adapt continuously. The ability to accumulate new information, the ability to adapt and apply new knowledge and technologies, the capacity to focus on results and problem-solving, social and interpersonal skills in order to be an effective team player, all these become crucial for the labour force. 
Higher education institutions have to professionally respond to all current challenges while keeping the balance between

- the need for mass education that is justified not only by reasons linked to equal rights and economic efficiency, but also by the fact that knowledge-based economy needs new competences and a higher qualification of the labour force, and

- the need for excellence in education in the context of fierce competition.

According to the European framework [1], universities must be able to develop competences for life $-a$ multifunctional package of knowledge, abilities and attitudes necessary for personal fulfilment and development, for social inclusion, active citizenship and sustainable employability in a knowledge-based society. This requires a focus on transversal competencies (soft skills): communication in general (online communication in particular), team work, cooperation, social responsibility, and ethics. Students must be prepared to be able to react and innovate in an ever changing world. There are new abilities needed: the ability to anticipate, rapid reaction, the ability to communicate in inter- and multicultural environments.

In the $21^{\text {st }}$ century, the increase in the importance of higher education in a knowledge-based society goes hand in hand with an increase in the mobility of students and discontinue biographies. In parallel with such trends there is higher demand for study programs that are modular, flexible, and adaptable for individual biographies.

The current global context requires also responsible citizens that assume an active role in their community, citizens with solid values, with respect for the environment, for the democratic values, for human rights, for cultural diversity, citizens capable to contribute to a world of peace and tolerance.

The higher education system is facing the challenge to address all characteristics of the new society. The training of students for their professional life has to be anchored in reality. Students have to be prepared not only to respond to the needs of the labour market but also to become active citizens, involved in finding solutions for their group, for the community they live in. Through education, the young generation should embrace a solid system of values that will make them responsible citizens.

\section{Competences for the future}

Young generations have to be prepared for their future professional activities and for their personal life by acquiring a solid cluster of knowledge, skills and attitudes.

Empirical studies performed worldwide showed that nowadays employers look for resourceful individuals. They look for both hard skills and soft skills, in different proportions depending on the profession/job. While schools and universities provide mostly the hard skills to their students (it is easier to teach, test and certify), soft skills are more difficult to be learned (it takes more emotional intelligence, mostly learned through experience, by practicing).

Different careers require a different mix between hard and soft skills. For sure a doctor needs in the first place the hard skills: biology, chemistry, and physics. Of course, they need also some soft skills: team work, good communication.

Still, in the current dynamic context, soft skills become very important because they help individuals to adapt and respond to different, challenging circumstances.

Employers consider that it is important to have the knowledge, but they want individuals able to work in teams and under pressure, good communicators, willing to learn through experience, capable to adapt to changing situations. Hard skills are important. Traditionally, it was considered that they are the most important 
to succeed in academia and in career. Soft skills become more important in current context, enhancing employability.

OECD member states launched in 1997 the DeSeCo Project (Definition and Selection of Competencies) in order to provide a framework for the key competencies individuals need to acquire in order to face today's challenges [2]. As mentioned by the experts in the project, value in current context is placed on flexibility, entrepreneurship and personal responsibility. Individuals are expected to adapt quickly, to be innovative and creative, to be self-directed and self-motivated. In the final report published in 2003 [3], the key competencies required in order to be able to deal with the demands of a complex world were classified in three categories:

1. Use tools interactively:

a. Use language, symbols and texts interactively;

b. Use knowledge and information interactively;

c. Use technology interactively.

2. Interact in heterogeneous groups:

a. Relate well to others;

b. Cooperate, work in teams;

c. Manage and resolve conflicts.

3. Act autonomously:

a. Act within the big picture;

b. Form and conduct life plans and personal projects;

c. Defend and assert rights, interests, limits and needs.

Sir Kenneth Robinson, educationalist, advisor on education to governments and education bodies, in his 2001 book Out of our Minds: Learning tobe Creative pointed out that in a rapid changing world organizations need people that are creative, communicate efficiently and work in teams; people that are flexible and able to adapt to different situations [4]. Creativity is not a luxury. It is essential for personal security and fulfilment.

American Chamber of Commerce in Romania (AmCham) having as member representatives of several hundreds of big employers on the Romanian market has decided to play an active role in training young generation, future employees in these companies and has created an AcademiaBusiness Council [5].

The aim of this council is to develop a platform for dialogue between universities and employers for a better insertion of graduates in the labour market. One of its objectives was to provide universities with a list of competences employers look for when they hire new employees. The Council's members have agreed on three categories of competences universities have to develop to their students, with the following ranking:

1. Soft skills (interrelationship skills, ability to work in teams as a member and/or leader, communication skills both in written and orally, focus on result/solutions, personal efficiency, self-development, initiative, ethical behaviour);

2. Linguistic skills (foreign languages: English is a must. There is a competitive advantage mastering other languages, especially rare ones);

3. Technical skills (professional skills related to the specialization they graduated from).

\section{LBUS case study: initiatives, experiences, good practices}

The strategic capacity of Romanian universities is limited by the restrained autonomy they have due to excessive, detailed legislation, on one hand, and the continuous change of rules and regulations and the under-financing on the other hand. The increase of the capacity of universities to adapt to the changing needs of the labour market and to the challenges of the economic and social environment in which they perform depends on increasing their autonomy by creating a legal framework that allows universities to define their own strategies in order to differentiate themselves in the market.

In order to develop a realistic strategy 
for 2020 by understanding the current national and international context in which it operates, "Lucian Blaga" University of Sibiu (LBUS) decided to perform a stakeholder analysis. Thus, the LBUS Strategy 2020 Sustainability and excellence for community - was developed on 5 pillars that correspond to current challenges:

- Teaching and learning;

- Research, development and innovation;

- Internationalization;

- Engagement in community;

- Governance.

In accordance with its vision for 2020, LBUS will be a modern university, focused towards the academic needs of its students and of the society, anchored in the national and international research map. LBUS will be an education and research institution that operates at high quality standards, will be attractive for its students from Romania and abroad and will be a valuable member of the local community [6].

According to this strategy, LBUS will be the main vehicle of knowledge transfer to the economic and social environment of the region. The LBUS Strategy reflects a realistic and responsible attitude focusing on the needs of its stakeholders: students, graduates, employers, community.

In a knowledge-based economy, the demand for qualified graduates is increasing. Graduates should have not only professional competences specific to their field of expertise, but the capacity to adapt to the dynamic needs of the labour market. The answer for such challenges is lying in the active collaboration between all stakeholders, and in this respect, the university should create viable partnerships not only with the employers, but also with the high schools from where it is recruiting the future students.

In a global economy, where not only the financial resources, but also the human ones move free, graduates will work in companies that act not only on the domestic market, but also on the European and international market, and in this context they have to be able to work in multicultural environments. LBUS paid attention in this context to internationalization at least on two directions:

- Student mobility through the ERASMUS program - allows students to spend one semester or one year in a different education system, getting used to students/young people with different cultural backgrounds and different experiences, speaking different languages

- Internationalization "at home" by revising and adapting the curricula to international standards and by attracting foreign students in order to create cultural diversity in the campus.

The understanding of the management team of LBUS is that the durable development of an organization is hindered in the first place not by technical and financial problems, but by relational ones. The difficulties are lying in the external economic and social environment. This is generating the need for a permanent dialogue with all stakeholders. The LBUS is aiming to be an active pillar of the community by developing educational programs adapted to respond to the needs of a dynamic community.

In order to be able to be connected to the changes that take place in the labour market and to address the needs of its stakeholders, LBUS has formalized the communication with graduates and employers by creating two entities: the Advisory Board (members are employers and representatives of the local authorities) and Alumni. Regular meetings organized with both employers and graduates may result in common projects that help university to educate students according to market needs.

The partnerships developed by the university with the companies that are active in the region allow to organize internships for the students, to develop common projects in which both students and professors get 
involved, to have practitioners as guest speakers for different courses that bring their expertise to students.

Through education and research, LBUS has to respond to the society's needs and to contribute to a better quality of life. How can LBUS be involved in solving the problems of the society? It can be involved by delivering quality services in education and training, by continuous forming of the human resources, by disseminating the research and innovation outcomes, by active involvement in the socio-cultural life of the community.

"Lucian Blaga" University of Sibiu is recognized locally, regionally and nationally for the value and the impact of its services on the community. LBUS is an active partner in the cooperation with the private sector and the local and national authorities.

LBUS is also looking for strengthening the students' engagement with the university through volunteering, civic, social and cultural activities. Creating a positive climate in which students feel that the university cares about them is considered essential. In this respect, LBUS puts considerable effort in finding solutions for students' needs, in designing and engaging in social and cultural activities, in offering support to students' associations.

\section{Conclusions}

Taking into consideration the rapid and profound changes that take place in the global economy, universities can no longer provide to students all the knowledge and skills they need in order to perform in their professional life. So, life-long learning becomes compulsory.

In consequence, the focus on creating a solid foundation for preparing a young professional for a specific domain and in developing the skills that will allow him/her to learn and adapt over time becomes more important. In this context, enhancing the soft skills of students has at least the same importance if not a higher one in the instruction provided within the formal school: know how to learn, self-motivation, determination, initiative, creativity, responsibility, result-oriented, teamwork, communication, ethics, time management, problem-solving, critical thinking, leadership.

Universities have to face these challenges and have to adapt their approach and teaching strategies in order to allow developing a proper mix of knowledgeskills-attitudes to students in order to respond professionally to the fast changing needs of the society.

\section{References}

[1] European Commission, Education and Training 2020 Work programme, Thematic Working Group "Assessment of Key Competences”, 2012, www.ec.europa.eu/education

[2] www.oecd.org/edu/statistics/deseco

[3] Dominique Simone Rychen and Laura Hersh Salganik (eds.), Key competencies for a Successful Life and a Well-Functioning Society, Hogrefe \& Huber, Gottingen, 2003

[4] Ken Robinson, O lume ieșită din minți. Revoluția creativă a educației, Publica, 2011

[5] www.amcham.ro

[6] LBUS, Strategy 2020 - Sustainability and Excellence for Community, 2014, www.ulbsibiu.ro 